\title{
Telomere length dynamics in human memory T cells specific for viruses causing acute or latent infections
}

\author{
Joel M O'Bryan' ${ }^{1}$, Marcia Woda ${ }^{1}$, Mary Co ${ }^{1}$, Anuja Mathew ${ }^{1 *}$ and Alan L Rothman²
}

\begin{abstract}
Background: Declining telomere length $(T L)$ is associated with $T$ cell senescence. While $T L$ in naive and memory $T$ cells declines with increasing age, there is limited data on TL dynamics in virus-specific memory CD4 ${ }^{+} \mathrm{T}$ cells in healthy adults. We combined BrdU-labeling of virus-stimulated T cells followed with flow cytometry-fluorescent in situ hybridization for TL determination. We analyzed TL in T cells specific for several virus infections: non-recurring acute (vaccinia virus, VACV), recurring-acute (influenza A virus, IAV), and reactivating viruses (varicella-zoster virus, VZV, and cytomegalovirus, CMV) in 10 healthy subjects. Additionally, five subjects provided multiple blood samples separated by up to 10 years.
\end{abstract}

Results: VACV- and CMV-specific T cells had longer average TL than IAV-specific CD4 ${ }^{+} \mathrm{T}$ cells. Although most virus-specific cells were CD45RA; we observed a minor population of BrdU+ CD45RA ${ }^{+} T$ cells characterized by long telomeres. Longitudinal analysis demonstrated a slow decline in average TL in virus-specific T cells. However, in one subject, VZV reactivation led to an increase in average TL in VZV-specific memory T cells, suggesting a conversion of longer TL cells from the naïve $T$ cell repertoire.

Conclusions: TLs in memory CD4 ${ }^{+} \mathrm{T}$ cells in otherwise healthy adults are heterogeneous and follow distinct virus-specific kinetics. These findings suggests that the distribution of TL and the creation and maintenance of long TL memory T cells could be important for the persistence of long-lived T cell memory.

Keywords: Ageing, Telomere, T cell memory, CD45RA, FlowFISH, Influenza A virus, Cytomegalovirus, Vaccinia virus, Varicella zoster virus, BrdU labeling

\section{Background}

Virus-specific $\mathrm{T}$ cell proliferative responses are detectable for decades after the initial infection [1-3] but how this $\mathrm{T}$ cell memory is established and maintained is not clear. Telomere length (TL) has been shown to be a critical determinant of $\mathrm{T}$ cell replicative capacity and in vivo persistence in humans; clinical trials have clearly shown that adoptive transfer of minimally-expanded tumorinfiltrating lymphocytes with long telomeres correlated with better in vivo persistence and proliferation, while excessive in vitro expansion prior to adoptive transfer

\footnotetext{
*Correspondence: anuja.mathew@umassmed.edu

'Division of Infectious Diseases and Immunology, University of

Massachusetts, Medical School, Worcester MA, USA

Full list of author information is available at the end of the article
}

lead to shortened telomeres, and correlated with poor in vivo persistence $[4,5]$.

Low frequencies of virus-specific $\mathrm{T}$ cells and the limited number of known virus epitopes has restricted the ex vivo study of TL mainly to $\mathrm{CD} 8^{+} \mathrm{T}$ cells specific for a few immunodominant epitopes with more limited studies of $\mathrm{CD}^{+} \mathrm{T}$ cells [6-9]. Despite robust $\mathrm{CD} 8^{+} \mathrm{T}$ cell responses during a primary infection, $\mathrm{CD} 4^{+}$memory $\mathrm{T}$ cell responses have been reported in some studies as more durable than $\mathrm{CD}^{+} \mathrm{T}$ cell responses [2,10-12]. Differing abilities of $\mathrm{CD}^{+}$and $\mathrm{CD}^{+} \mathrm{T}$ cells to up-regulate telomerase during activation and thus enhance telomere maintenance during this activation-induced proliferative phase have been proposed to account for these differences [13].

Memory $\mathrm{T}$ cells turnover in vivo more rapidly than naïve T cells [14-16]. However, T cells undergoing antigen-

\section{Biomed Central}


independent homeostatic proliferation do not express the high levels of telomerase necessary to prevent replicationdriven TL erosion [17-19]. This increased memory T cell turnover and lack of telomerase should theoretically lead to the senescence and loss of the proliferative capacity of memory $\mathrm{T}$ cells within a decade. On the other hand, periodic antigen-driven reactivation of memory $\mathrm{T}$ cells specific for recurrent or latent infections could drive additional rounds of proliferation with expression of telomerase to explain their continuing persistence $[17,20]$, although other data suggest that telomerase expression declines with each round of activation [19]. But this explanation fails in the face of reports of detectable poxvirus-specific T cells 5 to 6 decades after a smallpox vaccination, a situation where there are no recurring exposures [2]. Recently, the demonstration in humans and non-human primates of the presence of a T cell memory subset with stem cell-like renewal properties, termed $\mathrm{T}_{\mathrm{SCM}}$ cells, may provide a basis for the persistence of very long-lived $\mathrm{T}$ cell memory [21,22]. A substantially increased TL in this memory subset, relative to more differentiated memory $\mathrm{T}$ cells, could provide a mechanistic explanation for the in vivo longevity of the $\mathrm{T}_{\mathrm{SCM}}$ cells.

Virus-specific memory $\mathrm{T}$ cells are maintained in vivo under diverse conditions. Two common latent-reactivating herpesviruses differ in their host interactions; cytomegalovirus (CMV) is thought to establish latency in a wide range of tissues and cell types, especially myeloid cells, and may reactivate frequently, whereas varicella-zoster virus (VZV) establishes latency only in ganglionic neurons and reactivates infrequently [23,24]. Nevertheless, both require lifelong $\mathrm{T}$ cell-mediated immunity for their control within latently infected hosts $[25,26]$. Patterns of antigen exposure also differ for acute viral infections, such as influenza A virus (IAV), to which humans are likely repeatedly (seasonally) exposed, and vaccinia virus (VACV), a poxvirus with a quite limited exposure outside of the controlled vaccination setting. We used in vitro BrdU labeling to detect virus-specific memory $\mathrm{T}$ cells based on proliferation in response to virus stimulation, and then used flow cytometry fluorescence in situ hybridization (flowFISH) to measure TLs in virus-specific (BrdU+) cells. Importantly, flowFISH allows for the analysis of individual cells and can be multiplexed with (a limited number of) cell phenotypic markers such as CD45RA [27].

We first developed and validated a modified flowFISH $\mathrm{TL}$ assay on in vitro-expanded T cells by comparison with Southern blotting telomere restriction fragment length (TRF) results. We then performed a cross-sectional study of 10 healthy adults, with 5 of these subjects providing sequential samples which allowed for a longitudinal study of $\mathrm{T}$ cell TLs. Our results reveal diverse effects of virus reinfection and reactivation on T cell TL and the maintenance of $\mathrm{T}$ cell memory.

\section{Results}

FlowFISH analysis of T cell telomere length in in vitro-expanded $\mathrm{T}$ cells

We sought to compare TL in memory T cells in healthy adults specific for viruses causing acute (VACV, IAV) versus latent (VZV, CMV) infections. Since the frequency of virus-specific memory $\mathrm{T}$ cells in $\mathrm{PBMC}$ is generally too low in healthy humans for a robust TL analysis directly ex vivo, we expanded PBMC in vitro with viral antigens. To determine how this in vitro expansion may have affected TL, we compared TL in total T cells isolated from fresh PBMC to in vitro-expanded $\mathrm{T}$ cells using flowFISH [28]. Initial flowFISH experiments revealed inflated TL measurements in the in vitro expanded T cells $(p<0.001$, Figure 1A left bars). However, these flowFISH-derived TL estimates differed from TRF Southern blotting results (compare Figure 1B with Figure 1A left bars), where the TRF results were similar for the expanded $\mathrm{T}$ cells and those analyzed ex vivo. This suggested that the inflated flowFISH TL estimate was an assay artifact.

We therefore tested several modifications to the flowFISH protocol. Inclusion of a pre-hybridization fixationpermeabilization step substantially reduced the inflated telomere probe fluorescence, resulting in mean TL estimates closer to the TRF results (Figure 1A middle bars). We further added an RNase treatment step [29], in light of reports that telomeres are transcribed and thus providing additional targets for binding of the flowFISH telomere peptide nucleic acid (PNA) probe [30,31]. We optimized the RNase concentration and treatment times using a separate PNA probe to the 7SK small nuclear RNA [32] to ensure this protocol provided nuclease access to and digestion of nuclear-localized RNAs (data not shown). The combination of these steps gave minimized background fluorescence for the Cy-5 labeled telomere probe (Additional 1: Figure S1) and produced flowFISH TL estimates in agreement with the TRF results (Figure 1A right bars).

\section{TL measurement in T lymphocytes that proliferate to viral antigens}

Flow cytometry gating allowed discrimination of $\mathrm{CD} 4^{+}$ $\mathrm{T}$ cell subsets and estimation of TL in each subset (Figure 2A). Others have shown that the AlexaFluor ${ }^{\circledR}$ dyes and related organic small molecule dyes survive the in situ hybridization protocol and are useable, albeit with a somewhat reduced intensity, for flowFISH [33,34]. Although the hybridization altered the intensity of $\mathrm{CD}^{+}$and $\mathrm{CD}^{+}$ staining (Figure 2A, far right panel), the two primary $\mathrm{T}$ cell subsets $\left(\mathrm{CD} 4^{+} \mathrm{CD}^{-}\right.$versus $\left.\mathrm{CD} 4 \mathrm{CD}^{+}\right)$could be reproducibly defined (Additional 1: Figure S2). To identify T cells that proliferated to virus antigen, we labeled cells with BrdU during the final $72 \mathrm{~h}$ of a 7 day incubation and stained with a fluorochrome-conjugated anti-BrdU antibody after telomere probe hybridization. The flowFISH 


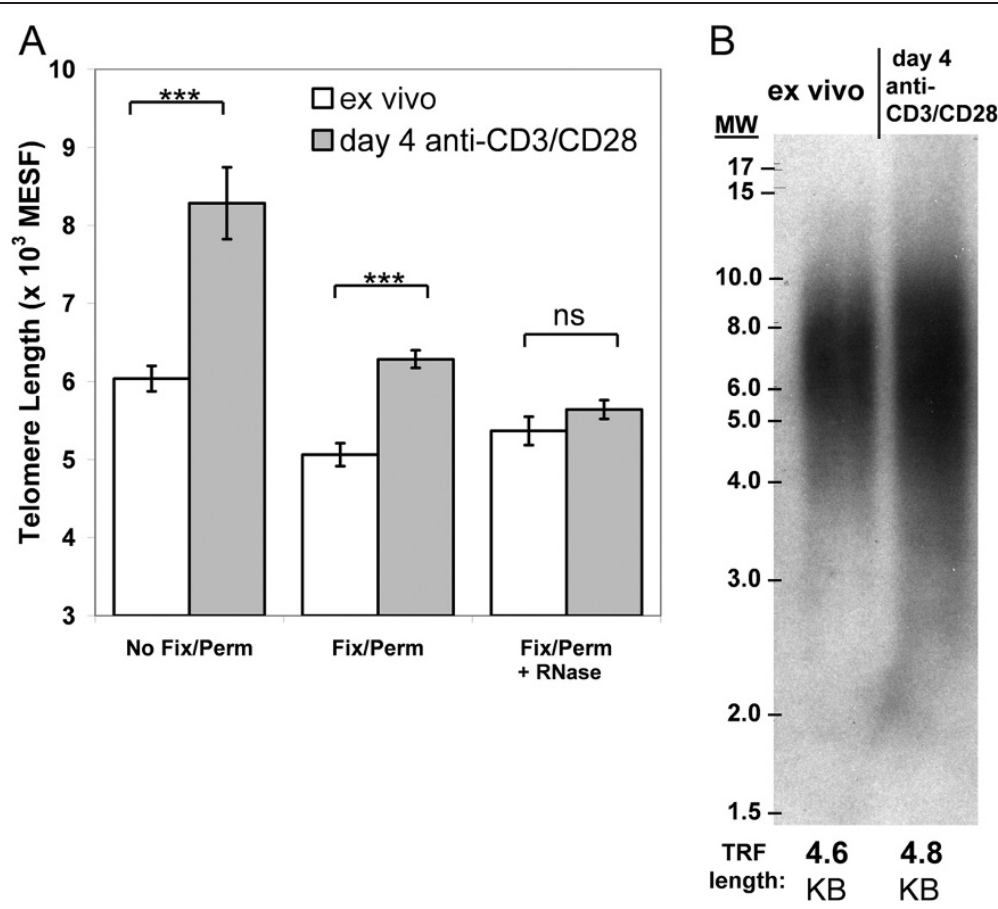

Figure 1 Telomere length (TL) measurement using flowFISH on proliferating T lymphocytes depends on fixation-permeabilization and RNA nuclease treatment. PBMC from healthy adults were either stimulated with immobilized anti-CD3 and anti-CD28 for 4 days or were cryopreserved on day 0 and thawed for processing on day $4 ; \mathrm{CD}^{+} \mathrm{T}$ cells were magnetically sorted from both samples on day 4 . Each sample was divided for flowFISH TL analysis and telomere restriction fragment (TRF) Southern blotting. (A) FlowFISH analysis using 3 different pre-hybridization conditions: without fixation-permeabilization prior to probe hybridization (no fix/perm), with fixation-permeabilization (Fix/Perm) prior to hybridization, and with fixation-permeabilization followed by RNase treatment prior to hybridization (Fix/Perm +RNase). Statistical comparisons were done using unpaired $t$-test, ${ }^{* *} p<0.001$, and $n s=n o t$ significantly different. (B) TRF Southern blot analysis. DNA was extracted from CD3+ T cells isolated ex vivo or after stimulation with anti $C D 3+C D 28$ for four days and subject to Southern Blot Analysis. TRF lengths are shown at the bottom of both lanes and are the average of three separate 20 pixel-wide analyses using MatLab software running the MaTelo macro (see Methods).

protocol accommodated anti-BrdU staining as a posthybridization step (Figure 2A).

We determined the specificity of in vitro proliferation to the viral antigens. It is difficult to identify subjects who have not been exposed to IAV or VZV. For CMV, seronegative status may not represent individuals who are truly CMV naïve by more sensitive PCR methods [35]; in contrast most have limited exposure to VACV outside of vaccination. Evidence for CMV-specific memory T cells in CMV seronegative healthy adults has recently been reported [36]. We therefore tested responses to VACV in PBMC collected from five subjects prior to initial smallpox vaccination to determine the specificity of the in vitro response and provide insight to the background levels of BrdU staining in negative controls. In these pilot studies, $\mathrm{CD}^{+} \mathrm{T}$ cells in PBMC from all subjects readily responded to IAV antigen, while responses to VACV antigen in PBMC samples prior to vaccination with VACV were close to the media-only control (Additional file 1: Figure S3). Accordingly, we used a BrdU+ T cell frequency of 5-fold or higher above the control culture of media-only background proliferation as the criterion for a positive response. $\mathrm{CD} 4^{+} \mathrm{T}$ cells from nine of our ten healthy adult subjects proliferated to
CMV antigen by this criteria; $\mathrm{CD}^{+} \mathrm{T}$ cells from all subjects met this positive response criteria to IAV, VACV, and VZV (Table 1). $\mathrm{CD}^{+}$and $\mathrm{CD}^{+}$responses from a typical subject are shown in Figure 2B. Proliferative responses in $\mathrm{CD}^{+} \mathrm{T}$ cells in these antigen-stimulated cultures were generally lower; therefore the cross-sectional study results presented here are limited to $\mathrm{CD}_{4}^{+} \mathrm{T}$ cell responses.

The use of CD45RA staining allowed for TL measurement in the mostly naïve non-proliferated $\left(C D 45 R A^{+}\right.$ $\left.\mathrm{BrdU}^{\text {neg }}\right) \mathrm{T}$ cell subsets as a point of reference for each subject (Figure 2A). Although the CD45RA ${ }^{+}$phenotype does not exclusively identify naïve $\mathrm{T}$ cells, this marker captures the naïve $\mathrm{T}$ cells, which typically form the majority of this phenotype in vivo in healthy young and mid-life adults. Importantly for our use here, this BrdU$\mathrm{CD}_{45 \mathrm{RA}^{+}}$subset from the media-only control for each donor provided a TL context to allow for a point of reference for each individual's memory TL comparisons. TL in CD45RA ${ }^{+} \mathrm{T}$ cells cultured in vitro correlated well with TL in CD45RA ${ }^{+}$cells ex vivo (Additional 1: Figure S4A). To evaluate the diversity in TL distribution in each sample, the single-cell flowFISH enabled an evaluation of median TL and the coefficient of variation (CV) 

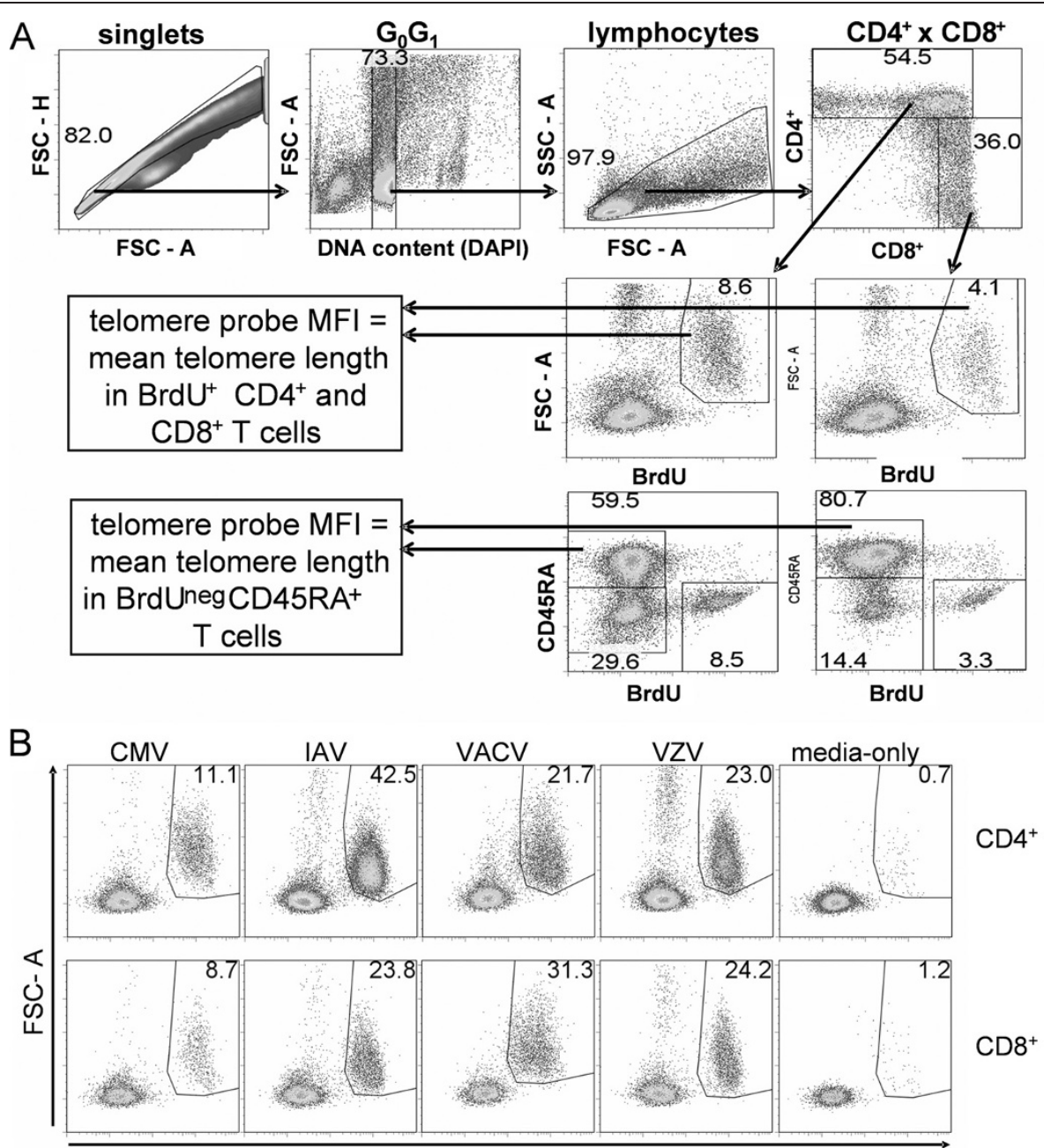

C

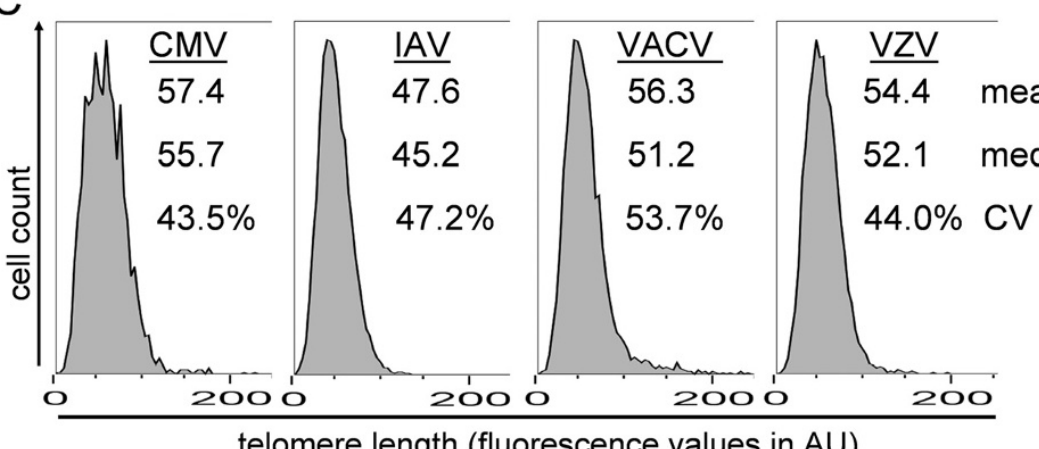

Figure 2 BrdU-flowFISH allows for TL measurement in proliferating $\mathrm{CD}^{+}$and $\mathrm{CD} 8^{+} \mathrm{T}$ lymphocytes. (A) Flow cytometry gating strategy for $T L$ measurement from probe mean fluorescence intensity (MFI) in BrdU ${ }^{+} \mathrm{CD}_{4}^{+}$and $\mathrm{CD} 8^{+}$cells and in BrdU-negative naïve $\left(\mathrm{CD} 45 \mathrm{RA}^{+}\right) \mathrm{T}$ cells. (B) Representative proliferative responses (BrdU+ FSC-A ${ }^{\text {high }}$ population) of CD4+ and CD8+ T cells to viral antigen. Values shown are frequencies of $\mathrm{CD}^{+}$or $\mathrm{CD}^{+} \mathrm{T}$ cells that were BrdU+. (C) Histograms of $\mathrm{TL}$ distribution for virus-specific $\mathrm{CD} 4^{+} \mathrm{T}$ cells defined as in $\mathbf{B}$. Mean and median fluorescence intensity values, in arbitrary units (AU), are shown for each plot. Coefficient of variation (CV) is also shown.

in addition to mean TL (Figure 2C). Replicate experiments on the same PBMC samples showed that TL measurements in proliferating (virus-specific) $\mathrm{T}$ cells were highly reproducible (Additional 1: Figure S4B, C) even when proliferation frequency differed slightly (Additional 1: Figure S3C). 
Table $1 \mathrm{CD}^{+} \mathrm{T}$ cell proliferation responses in PBMC from ten healthy donors

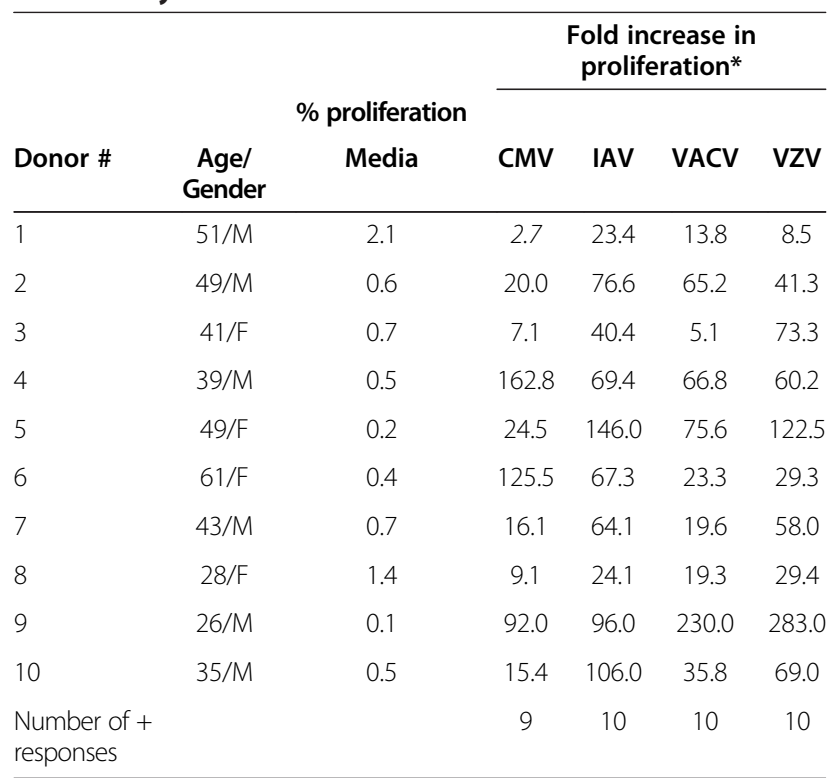

* Fold increase in proliferation is the ratio of the frequency of BrdU+ CD4+ T cells in response to virus stimulation divided by the $\% \mathrm{BrdU}+$ frequency in response to media.

Gender: M - male, F - female.

\section{$\mathrm{TL}$ and CD45RA ${ }^{+}$frequencies in proliferating $\mathrm{CD}^{+}{ }^{+} \mathrm{T}$ cells}

Since TL declines in normal somatic cells as a result of cell division in the absence of sufficient telomerase activity, it was important to understand the effects of in vitro expansion on TL in virus-specific T cells. Prior to day 5 , $\mathrm{BrdU}+$ cells were not detectable in antigen-stimulated cultures above the levels in background (unstimulated) cultures (data not shown). Starting at day 5, BrdU+ cells represented a small but distinct population (Figure 3A). However, day 5 and 6 cultures had T cell populations with highly skewed TL distributions and low BrdU+ cell numbers, which combined to produce a large variability in mean TL (Figure 3B, and data not shown). In contrast, at day 7 of culture, TL distributions had converged to more Gaussian distributions (Figure 3B) and were reproducible between replicate cultures (Additional 1: Figure S4C). Based on these experiments, we concluded that reproducible measurements of TL in virus-specific $\mathrm{T}$ cells could best be obtained at a 7-day culture, and that proliferating, activated $\mathrm{T}$ cells maintained relatively stable, reproducible TLs during at this time of activation-induced expansion.

Previous work has shown that virus-specific $\mathrm{CD}^{+} \mathrm{T}$ cells convert over several months after viral infection from an early population of proliferating, CD45RA $/ C D 45 \mathrm{RO}^{+}$ effector $\mathrm{T}$ cells to mostly quiescent, CD45RA ${ }^{+}$memory $\mathrm{T}$ cells with a high replicative capacity [7,37]. Similar to these results we found high $C D 45 \mathrm{RA}^{+}$frequencies in the proliferated BrdU+CD4 ${ }^{+} \mathrm{T}$ cells at day 5 and 6 , which decreased to day 7; the CD45RA effector fraction rapidly increased over the same period to become the dominant phenotype of the $\mathrm{BrdU}^{+}$population (Figure $3 \mathrm{C}$ ).

\section{CMV-specific and VACV-specific CD4 ${ }^{+} \mathrm{T}$ cells that proliferated have longer mean telomere lengths than similar IAV-specific $\mathrm{CD}^{+}{ }^{+}$cells}

We performed a cross-sectional study of 10 healthy adult subjects, who ranged in age from 26 to 61 years. Among the four viruses studied, IAV stimulation produced, overall, the highest frequency of BrdU+ $\mathrm{CD} 4^{+}$memory $\mathrm{T}$ cells (Figure 4A). Frequencies of $\mathrm{CD}^{+}{ }^{+} \mathrm{T}$ cells that proliferated to $\mathrm{CMV}$ were generally lower than the other three viruses, but were very high in two subjects. It must be noted that the AD-169 laboratory strain of CMV used in this study has a large genome deletion relative to wild-type CMV [38], which could contribute to lower proliferation. However, the gamma-irradiated non-replicating virus used as antigen still contains the wild-type virion structural proteins, and $\mathrm{T}$ cell responses are directed against the tegument and capsid proteins.

We found a wide range of mean TL in naïve and virusspecific $\mathrm{CD}^{+} \mathrm{T}$ cells in our study cohort (Figure 4B). In pair-wise comparisons, VACV-specific $\mathrm{CD}^{+} \mathrm{T}$ cell $\mathrm{TL}$ were significantly longer than IAV-specific $\mathrm{CD} 4^{+} \mathrm{T}$ cells, in both absolute TL $(\mathrm{p}<0.01$, Figure $4 \mathrm{C})$ and as a ratio to the subject's naïve T cell TL (Figure 4D). Counter to our expectation, we found that the $\mathrm{CMV}$-specific $\mathrm{CD} 4^{+} \mathrm{T}$ cell $\mathrm{TL}$ was also significantly longer than IAV-specific $\mathrm{CD} 4^{+} \mathrm{T}$ cell TL $(\mathrm{p}<0.05)$ in both absolute TL and as a ratio to naïve $\mathrm{T}$ cell $\mathrm{TL}$. The TLs in proliferating $\mathrm{T}$ cells were not merely an artifact of the amount in vitro expansion, since we found no correlation between TL and the percent BrdU+ cells (Figure 4E).

\section{VACV-specific memory $\mathrm{CD}^{+}{ }^{+} \mathrm{T}$ cells include a higher} frequency of $C D 45 R A^{+}$cells with long telomeres

We observed the consistent presence of $\mathrm{CD} 4^{+} \mathrm{T}$ cells with long telomeres in the virus-specific cell populations, which were predominately in the CD45RA+ gate (Figure $5 \mathrm{~A}$ ). The CD45RA+ fraction typically constituted $5-15 \%$ of virus-specific (BrdU+) cells at day 7 (Figures $3 \mathrm{C}$ and $5 \mathrm{~A}$ ), and was skewed toward longer TLs compared to the CD45RA- population (Figure 5A, B).

We compared the frequency of these long telomere $\mathrm{CD} 4^{+} \mathrm{CD} 45 \mathrm{RA}^{+}$cells in the four virus-specific T cell populations. For this analysis, we applied a consistent telomere probe MFI cutoff value for each subject (Figure 5C). We found that the frequencies of long telomere CD45RA ${ }^{+}$ cells were significantly greater in VACV-specific $\mathrm{T}$ cells than in IAV-specific T cells ( $\mathrm{p}=0.03$, Figure 5D). 


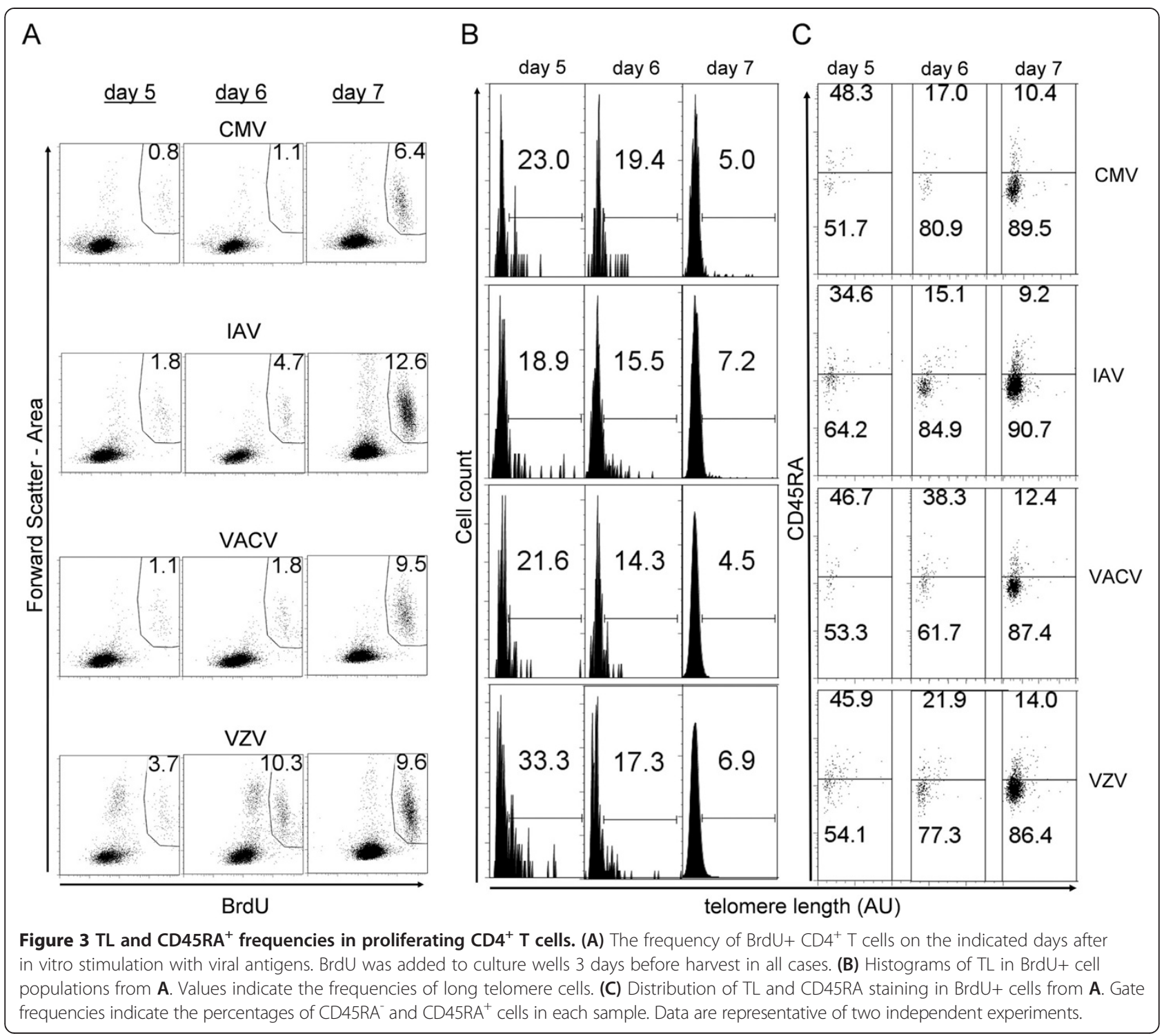

\section{Longitudinal analysis of virus-specific $\mathrm{CD} 4^{+} \mathrm{T}$ cell} telomere dynamics in healthy subjects

For five of our subjects, we had multiple PBMC samples collected over an 8 to 10 year interval. We compared TL of naïve $\left(\mathrm{CD} 45 \mathrm{RA}^{+} \mathrm{BrdU}^{\text {neg }}\right)$ and virus-specific $\mathrm{CD} 4^{+} \mathrm{T}$ cells from the first and last time points (Figure 6A, B). We used the average slopes and $y$-intercepts to graph the average TL kinetics (dashed lines in Figure 6B). Naïve (CD45RA ${ }^{+}$BrdU-) $\mathrm{CD} 4^{+} \mathrm{T}$ cells showed a downward slope in TL in all subjects, consistent with an age-dependent TL erosion [39]. Virus-specific CD4 ${ }^{+} \mathrm{T}$ cell also showed declining mean TL in the cohort as a whole; however, TL in CMV-, IAV-, or VZV-specific CD4 ${ }^{+} \mathrm{T}$ cells increased from the first to last time point in at least 1 subject.

The mean TL slopes (rate of TL decay) in CMV- and IAV-specific $\mathrm{CD}^{+} \mathrm{T}$ cells were similar, while the $\mathrm{TL}$ slopes in both the VACV- and VZV-specific $\mathrm{CD}^{+} \mathrm{T}$ cells were steeper and similar to the naïve TL decay rate (Figure 6C). None of the pairwise comparisons revealed statistically significant differences, although the difference between TL slopes in CMV-specific T cells and naive $T$ cells approached statistical significance in this small cohort $(\mathrm{p}=0.06)$.

\section{VZV reactivation was associated with an increase in VZV-specific T cell telomere lengths and proliferative responses}

From one healthy subject, we had obtained three PBMC samples over a period of three and a half years. We observed an unexpected, dramatic increase in both the BrdU+ frequency and mean TL in the VZV-specific CD4 ${ }^{+}$ (Figure 7A, C) and CD8 ${ }^{+}$(Figure 7B, D) T cells at the middle time point in this subject, while the other virusspecific responses were largely unchanged. Upon inquiry, 

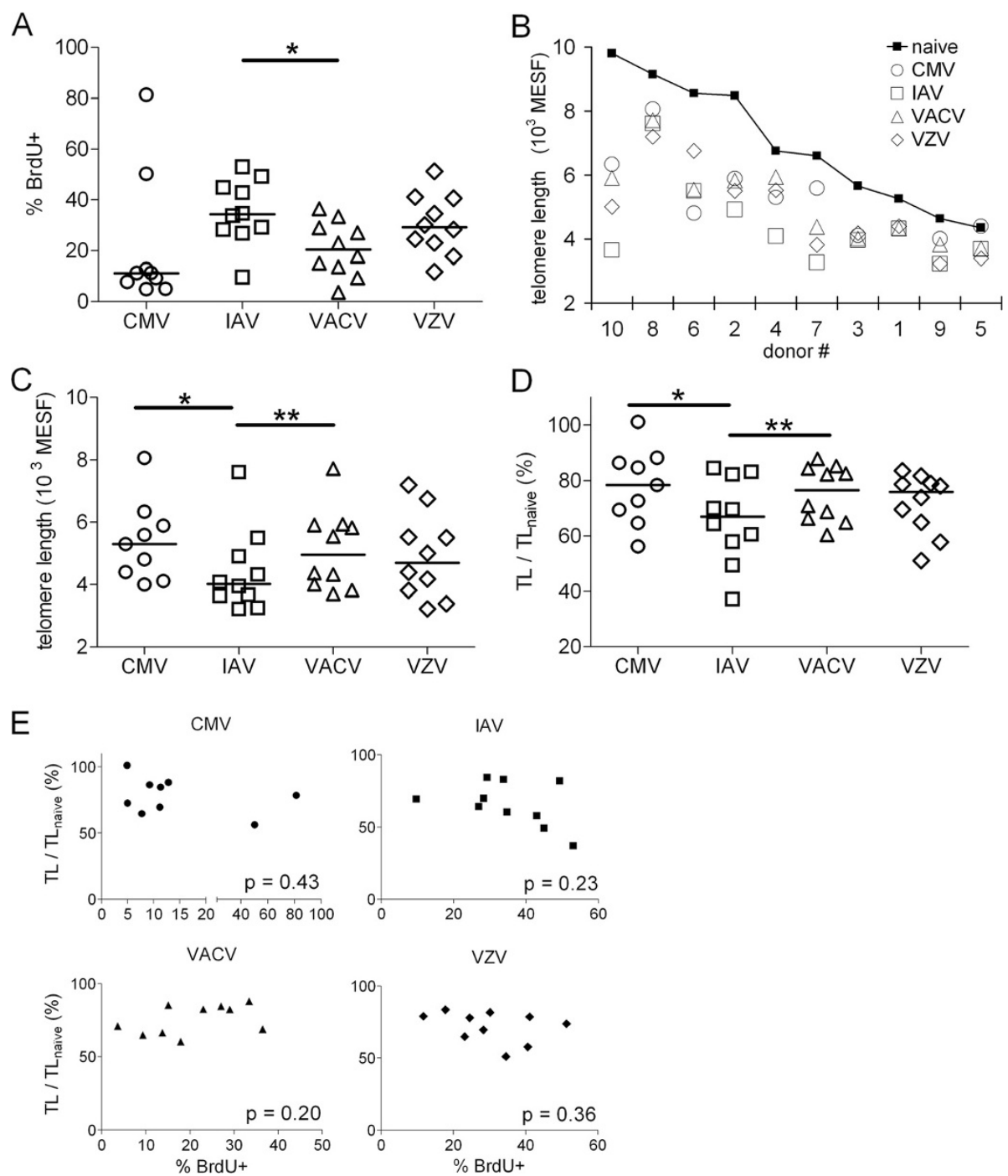

Figure 4 TL in CMV- and VACV-specific CD4 ${ }^{+} \mathbf{T}$ cells are longer than TL in IAV-specific CD4 ${ }^{+} \mathbf{T}$ cells. (A) Frequencies of BrdU+CD4 $4^{+}$ $\mathrm{T}$ cells in ten healthy adults. (B) Mean TL measured in $\mathrm{CD}^{+} \mathrm{T}$ cells grouped by subject in units of molecules of equivalent soluble fluorescence (MESF). (C) Absolute TL in $C D 4^{+} T$ cells grouped by virus. (D) $T L$ in $C D 4^{+} T$ cells that proliferated to viral antigen normalized to $T L$ in naïve $C D 4^{+} T$ cells (BrdU $\left.{ }^{\text {negative }} \mathrm{CD} 4 \mathrm{RA}^{+}\right)\left(T L / T L_{\text {naive }}\right)$ in the same subject. Statistical analyses: ${ }^{* *} p<0.01$, * $p<0.05$ by Wilcoxon paired, signed rank test. (E) Linear regression analyses for correlations between virus-specific proliferation frequencies $(\% \mathrm{BrdU}+)$ and $T L / T L_{n}$ aive. $\mathrm{P}$ values are from Pearson correlation and linear regression testing. For $C M V, n=9 ;$ all others, $n=10$.

this individual reported an episode of shingles approximately 2-3 weeks prior to this middle time point blood collection. These results strongly suggest that a clinically relevant herpesvirus reactivation can lead not only to a boost in the memory $\mathrm{T}$ cell frequency but also to dramatically increased TL in T cells. We further analyzed the CD45RA expression in these VZV-specific $\mathrm{CD}^{+}$and $\mathrm{CD} 8^{+}$ $\mathrm{T}$ cells in this subject (Figure 7E). While $\mathrm{TL}$ in $\mathrm{CD} 4^{+}$ CD45RA ${ }^{+}$BrdU $+T$ cells was not different from the TL in $\mathrm{CD}^{+}{ }^{+} \mathrm{CD} 45 \mathrm{RA}^{-} \mathrm{BrdU}+\mathrm{T}$ cells prior to VZV reactivation, it was significantly higher after VZV reactivation (Figure 7F).

\section{Discussion}

We measured TL in virus-specific $\mathrm{CD}_{4}^{+} \mathrm{T}$ cells in a cohort of ten healthy adult subjects. We incorporated a novel combination of BrdU staining for in vitro proliferation with a flowFISH TL assay modified with a prehybridization RNase step to shed light on TL dynamics in these $\mathrm{CD}^{+}$memory $\mathrm{T}$ cells. Under these experimental conditions of activation-induced proliferation these highly proliferative $\mathrm{T}$ cells maintained stable TL, likely due to up-regulation of telomerase $[13,17]$. Thus, we conclude that the differences in TL between virus-specific 


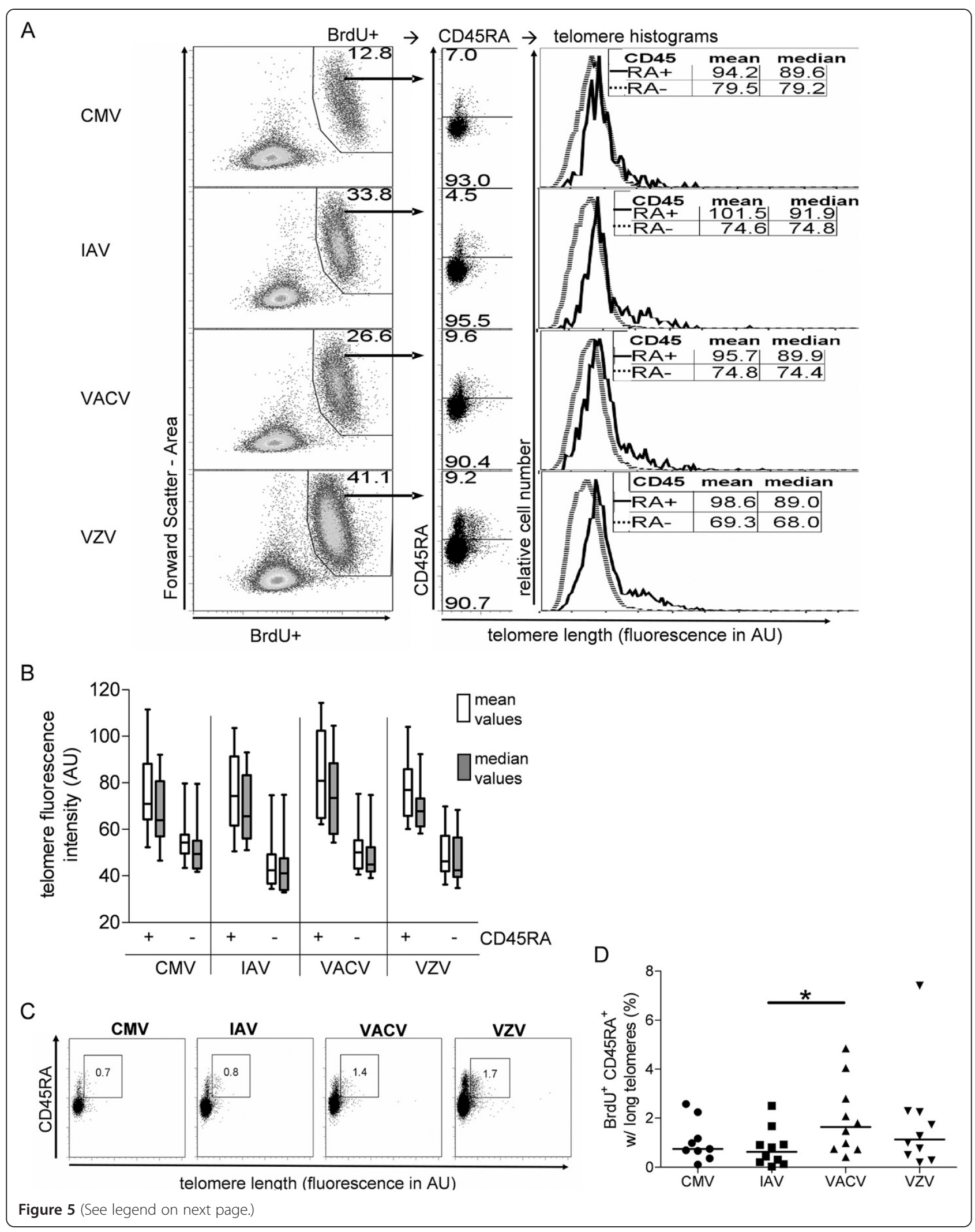


(See figure on previous page.)

Figure 5 VACV-specific memory CD4 ${ }^{+} \mathrm{T}$ cells have a higher frequency of CD45RA ${ }^{+}$cells with long telomeres. (A) CD4 ${ }^{+} T$ cell proliferative responses $\left(\mathrm{BrdU}^{+}\right)$gated by $\mathrm{CD} 45 \mathrm{RA}^{+/-}$from 1 subject. Histograms of TL in CD45RA and CD45RA ${ }^{+}$cells are overlaid, and mean and median fluorescence intensities for each population are shown. (B) Mean and median telomere probe fluorescence intensity values for all subjects' grouped by virus. Box and whisker plots indicate minimum to maximum values with the lines inside the boxes depicting the median values for each set of measurements. (C) Frequencies of BrdU ${ }^{+} \mathrm{CD}_{45 R A^{+}} \mathrm{CD}^{+} \mathrm{T}$ cells with long telomeres in one subject. (D) Frequency of CD45RA ${ }^{+} \mathrm{CD}^{+}$ $\mathrm{T}$ cells with long telomere within the BrdU+ population for 10 subjects. ${ }^{*} p<0.05$ by Wilcoxon paired, signed rank test. Fluorescence is shown in arbitrary units (AU).

T cell populations at day 7 of culture reflect actual differences in the in vivo TL distributions at the time of blood collection.

Our approach of using antigen stimulation to expand virus-specific $\mathrm{T}$ cells in vitro, as compared to ex vivo analysis of non-expanded cell populations based on HLApeptide tetramer staining or intracellular cytokine staining, avoids the limitation of studying only immunodominant epitopes recognized by a small subset of HLA alleles, and the biases that such limitations would introduce. It also allowed us to study CD4+ memory $\mathrm{T}$ cells specific for VACV and VZV, which have been detected at much lower frequencies than $\mathrm{T}$ cells specific for CMV. The greater number of cells used in the analysis also provides a more robust TL determination, an important consideration in identifying the subset of cells with longer telomeres. On the other hand, a disadvantage of this approach is that we cannot prove that all divided cells are antigen-specific, as the whole gamma-activated viral antigens may have resulted in some representing cytokine-driven proliferation. However, the frequencies of BrdU+ cells in the control samples (unstimulated PBMC and PBMC from VACV-na ive individuals) were low. Also, the expression of phenotypic markers may have changed as a result of in vitro culture, and therefore some of our findings, such as the relationship between CD45RA expression and TL, may not directly correlate with their in vivo counterparts.

Our finding that $\mathrm{TL}$ in $\mathrm{CD} 4^{+} \mathrm{T}$ cells specific for the non-recurring acute virus infection, $\mathrm{VACV}$, was longer than TL in T cells specific for the acutely infecting but recurring exposure virus, IAV, supports our initial model in which recurring antigen exposures drive a more rapid TL decay with age. A caveat to this interpretation is that each IAV infection may involve some new epitopes that activate naïve $\mathrm{T}$ cells (with longer TL).

However, we had also predicted that TL in CMVspecific $\mathrm{T}$ cells would be shorter than TL in T cells specific for VACV or IAV, but our results showed the opposite. There are likely several explanations for these observations. We did not survey an older (aged $>60$ years) adult cohort where clonal expansions of CMV-specific T cells with short TL are most prominent [40]. As described by others, CMV-specific CD4 ${ }^{+} \mathrm{T}$ cells may be continuously driven to replicative exhaustion in vivo with correspondingly short TL [6]. Our experimental approach of BrdU labeling only measured TL in T cells that proliferated in vitro in response to virus stimulation. Since BrdU was added to the culture medium on day $5, \mathrm{CMV}$-specific $\mathrm{T}$ cells driven in vivo to replicative exhaustion with corresponding shortened telomeres would not have been detected in our assay. The $\mathrm{CMV}$-specific $(\mathrm{BrdU}+) \mathrm{CD}^{+} \mathrm{T}$ cells with longer TLs may predominantly reflect memory $\mathrm{T}$ cells more recently converted from the naive repertoire. This interpretation supports the idea that CMV-specific $\mathrm{T}$ cell immunity is maintained by ongoing (periodic or continual) recruitment and activation of CMV-reactive naive $T$ cells. The small size of our longitudinal cohort and differing kinetics of TL decay of the different virus-specific $\mathrm{T}$ cells (Figure 6C) prevent statistically robust conclusions.

An inherent limitation of flowFISH is the limited number of cellular phenotype markers that survive the hybridization conditions [28]. On the other hand, single cell analysis methods such as flowFISH allow the derivation of additional metrics of TL distribution such as median and skewness, which may be informative to understanding the formation of long-lived $\mathrm{T}$ cell memory and which cannot be captured in population-derived Southern blotting and PCR-based TL determination methods [41]. Exploiting this capability, we identified a subset of BrdU+ $\mathrm{CD}^{+} \mathrm{T}$ cells with long TLs that were predominantly a CD45RA ${ }^{+}$phenotype. The long TLs in these highly pro-

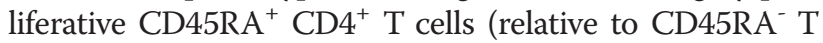
cell TL) would be advantageous to maintain very longlived cellular memory during periods without antigen reexposure to drive subsequent clonal expansions. Thus this long telomere mechanism of a substantial replicative reserve in this population is supported by the recently described long-lived human memory $\mathrm{T}_{\mathrm{SCM}}$ cell population with enhanced capacity for self-renewal, a population they also defined with a CD45RA ${ }^{+}$phenotype [42].

Our observations that TL in VZV-specific $\mathrm{CD} 4^{+}$and $\mathrm{CD}^{+}$cells increased by more than $50 \%$ in one subject after an episode of shingles have interesting implications. There are at least two models to explain this increase in TL in VZV-specific T cells: elongation of shortened telomeres in pre-existing memory $\mathrm{T}$ cells, or conversion of new naïve $\mathrm{T}$ cells (with their longer $\mathrm{TL}$ ) into memory phenotype $\mathrm{T}$ cells. Human T cells undergoing activationinduced proliferation have been shown to up-regulate telomerase, which has been proposed to maintain TL but 


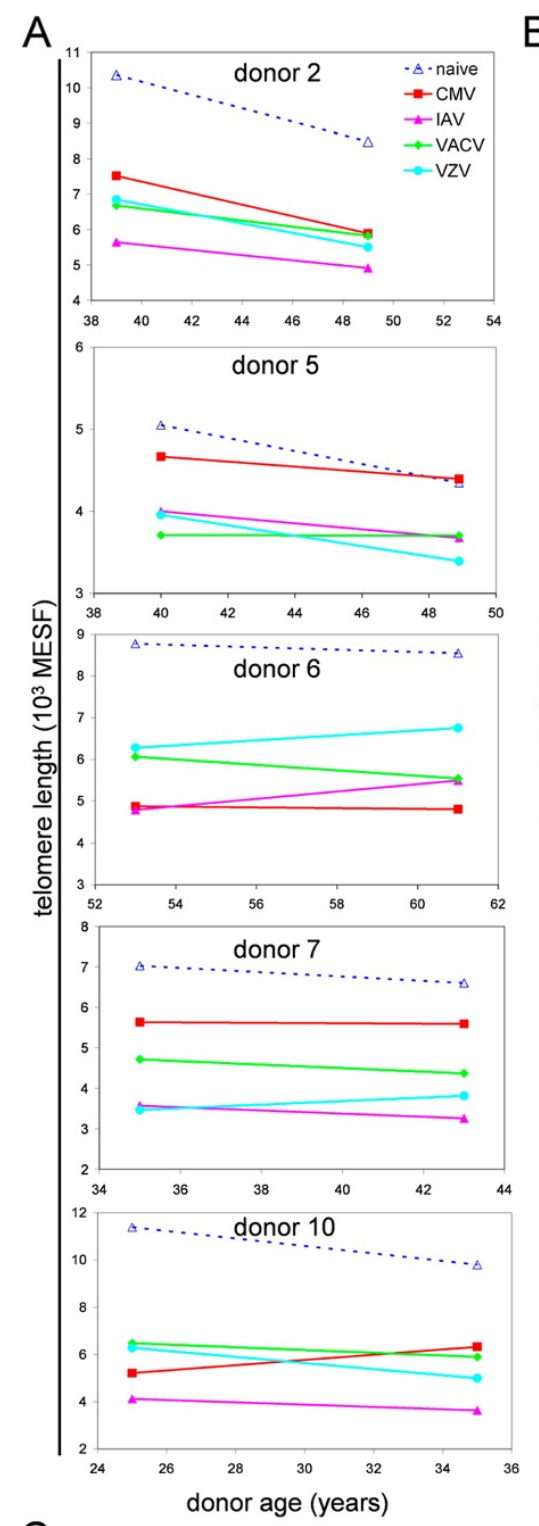

C

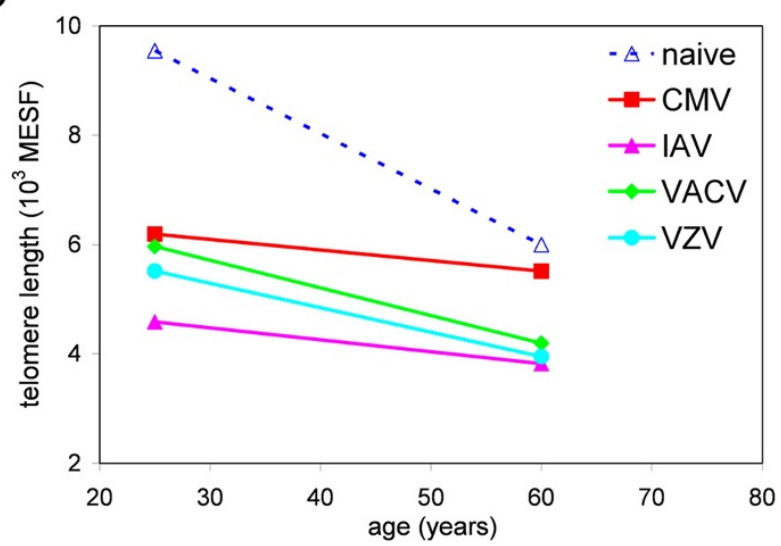

Figure 6 (See legend on next page.)

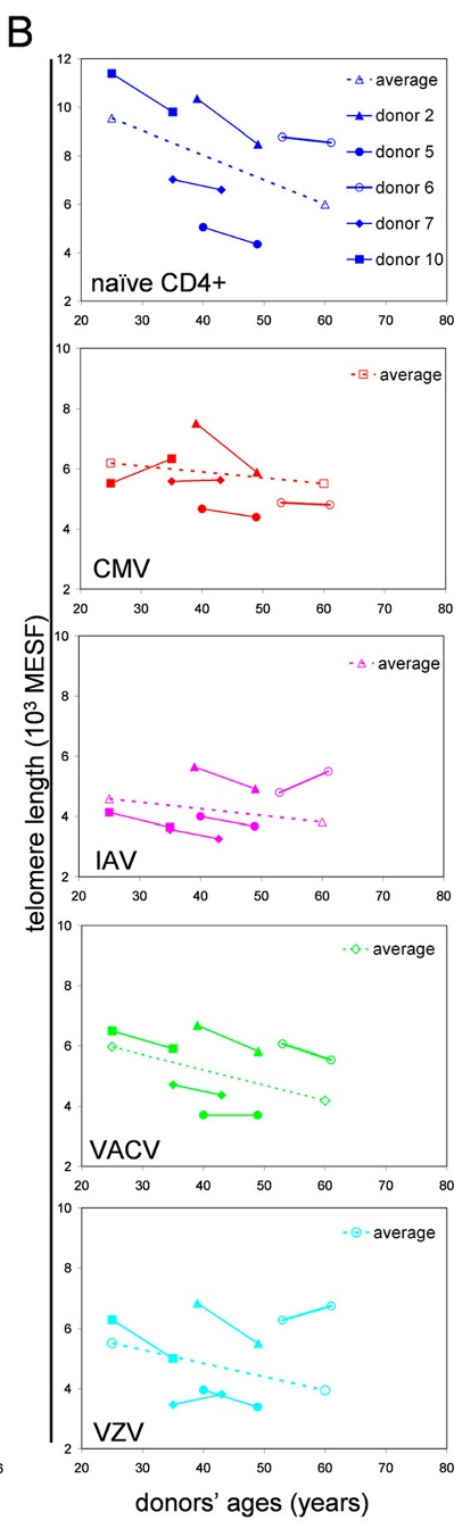


(See figure on previous page.)

Figure 6 Longitudinal analysis of TL in CD4 $4^{+}$virus-specific memory T cells. (A) TL was measured in $\mathrm{CD}^{+} \mathrm{BrdU}^{-} \mathrm{CD} \mathrm{R} 5 \mathrm{RA}^{+}$(dotted lines) and $\mathrm{CD}^{+} \mathrm{BrdU}+\mathrm{T}$ cells (solid lines) from five healthy subjects. PBMC samples were obtained 8 to 10 years apart. (B) The data from A were grouped according to different virus-specific T cell populations for all 5 subjects. Dotted lines are derived from the average slopes and y-intercepts. (C) Average TL kinetic of each virus-specific T cell population and naïve T cell average TL line from each plot in B is presented as single plot to allow comparisons of the average T cell TL kinetics in this cohort of healthy adults.

has not generally been considered sufficient for significant telomere elongation [20]. Thus we conclude that recruitment of new $\mathrm{T}$ cell clones from the naïve $\mathrm{T}$ cell repertoire is the more likely explanation for our data. The paucity of $\mathrm{CD}_{45 \mathrm{RA}^{+} \mathrm{VZV} \text {-specific CD4 }}{ }^{+} \mathrm{T}$ cells with long TL in the blood sample collected 2 years prior to VZV reactivation (Figure 7F) suggests the following scenario: a gradual loss of the long-lived reserve of CD45RA ${ }^{+}$memory $\mathrm{T}$ cells led to waning $\mathrm{T}$ cell effector-memory responses. Loss of effector $\mathrm{T}$ cell at sites of viral latency became inadequate to restrain VZV lytic phase reactivation leading to the clinical presentation of shingles in this subject with a subsequent renewal of VZV memory from fresh naïve $T$ cells [43]. This interpretation would be consistent with a requirement for a CD45RA ${ }^{+} \mathrm{T}_{\mathrm{SCM}}$ cell population to sustain, in the absence of lytic-phase virus production, the generation of more differentiated $\mathrm{T}$ cell effector memory clones, with negative consequences to host anti-viral control resulting when the $\mathrm{T}_{\mathrm{SCM}}$ reservoir becomes sufficiently depleted, as proposed by Restifo and colleagues [42]. The flowFISH-BrdU in vitro methodology presented here provides an avenue to further investigate a role for long telomeres in human $\mathrm{T}_{\mathrm{SCM}}$ cells.

\section{Conclusions}

Our analysis of TL in T cells that proliferate in response to virus stimulation and longitudinal TL modeling offers a pathway to further investigate TL kinetics of differing virus-specific memory $\mathrm{T}$ cell populations as we age. This linear TL modeling in mid-life healthy adults provides methodology to investigate how the age-dependent decline in TL in naïve T cells may eventually intersect with memory cell TL. An insufficiency in naïve T cell TL may lead to compromised virus-specific effector-memory $\mathrm{T}$ cells in advancing age and a less efficacious response to a recurring viral infection, including accelerated immunosenescence caused by CMV.

Although speculative due to our small cohort size, our data suggest that TL differences between various virusspecific $\mathrm{T}$ cell populations may be greater at younger ages as a result of differing exposures and infection histories, and these TL differences within an individual diminish as we age. Longitudinal studies of TL dynamics using a much larger cohort of healthy individuals are clearly needed to validate our results. The visualization of TL distribution in individual virus-specific $\mathrm{T}$ cells from a variety of chronic and acute infections, made possible with flow cytometry, should provide clearer insights to the factors affecting the generation, maintenance, and loss of long-lived $\mathrm{T}$ cell memory to different pathogens and vaccines.

\section{Methods}

\section{Ethics statement}

All blood samples were collected from healthy subjects in accordance with protocols approved by the University of Massachusetts Medical School Institutional Review Board. All subjects provided written, informed consent to participate.

\section{Study subjects}

We enrolled 10 healthy adults who had documentation of receiving the smallpox vaccine (3 months prior to blood collection in one subject and $>1$ year in all others). PBMC were separated using Ficoll-PaquePlus (GE Healthcare) or Histopaque-1077 (Sigma).

\section{BrdU proliferation assay}

For virus stimulation assays, freshly thawed PBMC were cultured at $2.75 \times 10^{5}$ cells per well in 96-well plates in complete media with a final volume of $200 \mu \mathrm{L}$ per well. Complete media consisted of RPMI-1640 (GibcoInvitrogen), L-glutamine, penicillin, streptomycin, and $10 \%$ human $\mathrm{AB}$ serum (Cellgro-Mediatech). Antigens added to wells were: gamma-inactivated influenza $\mathrm{A}$ virus (A/H3N2/Texas/77/1), human CMV (strain AD169), or VZV (strain VZ-10), all obtained from Microbix Biosystems Inc., Ontario, Canada, and used at a final dilution of 1:100. VACV (strain: NYCBH) propagated in our laboratory was used at an $\mathrm{MOI}=0.2 .72 \mathrm{~h}$ prior to culture harvest, bromodeoxyuridine (BrdU, BD Pharmingen) in complete media was added at a final concentration of $2 \mu \mathrm{M}$. All cultures were harvested on day 7 unless specified otherwise. A cutoff of 5-fold proliferation over background (from media-only culture) was used to define a positive response to virus stimulation. All samples from the same subject were analyzed in the same experiment.

\section{Telomere restriction fragment (TRF) Southern blot}

An aliquot of PBMC was stimulated for 4 days in 96-well plates pre-coated with anti-CD3 plus anti-CD28 $(3 \mu \mathrm{g} / \mathrm{mL}$ each) in complete media. On day 4 , a frozen aliquot was thawed, and both the stimulated and freshly thawed cells were magnetically sorted for $\mathrm{CD}^{+} \mathrm{T}$ cells using 


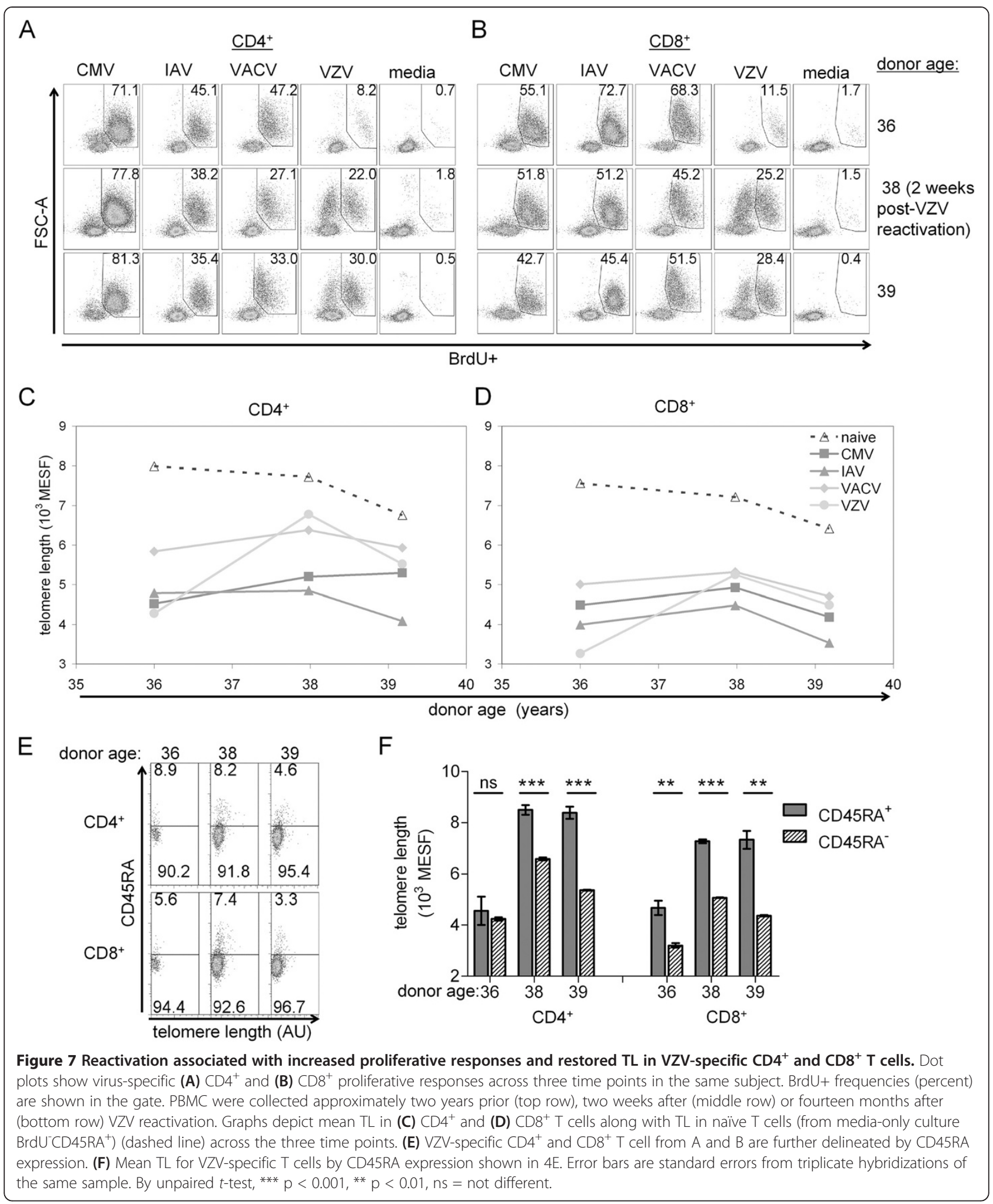

negative selection (Pan T cell isolation kit II, Miltenyi Biotec). Each cell sample was split into two aliquots, one for TRF Southern blot analysis and the other for telomere flowFISH (described below).
For TRF Southern blotting, DNA was extracted from $2 \times 10^{6} \mathrm{CD}^{+} \mathrm{T}$ cells using the Wizard Genomic DNA purification kit (Promega) which included an RNase digestion step. These DNA preparations were digested 
overnight with HinfI and RsaI restriction enzymes (New England BioLabs). Electrophoresis of one microgram of digested DNA per lane was performed on a $0.8 \%$ TBSagarose gel with TBS running buffer. Biotinylated molecular weight markers were run in adjacent lanes. Gels were depurinated, denatured, neutralized, and transferred overnight to a neutral membrane. The membrane was UV cross-linked and hybridized with a telomere G-strandspecific, fluorescein-labeled peptide nucleic acid (PNA) probe (FAM-OO-(CCCTAA) 3 , Panagene, South Korea). After high stringency washes and blocking, the telomere bands were developed and visualized using the Illuminator Chemiluminescent Detection System (Stratagene). The membrane was then stripped and the MW markers were visualized using streptavidin-alkaline phosphatase chemiluminescence. The two images were overlayed and MW marks transferred to the telomere probe image, which was then scanned at 1200 pixel per inch resolution. The resulting scanned image was analyzed with the MatLab (MathWorks) macro MATELO (http://md.technion.ac.il/ lecturers/lecturer_desc.asp?lecturerID=10\&departmentID = $1 \&$ contentCatID=4) [44].

\section{FlowFISH telomere length assay}

TL was measured in PBMC subsets using a flowFISH assay [28]. We incorporated RNA nuclease treatment prior to probe hybridization, as previously described [29]. Here we also included BrdU staining to identify cells that had proliferated. Multiple wells from each in vitro stimulation condition were pooled. PBMC or purified $\mathrm{CD}^{+} \mathrm{T}$ cells (1.5 to $2.5 \times 10^{6}$ cells from each sample) were stained at $4^{\circ} \mathrm{C}$ with Alexa700-anti-hCD4 and APC-eFluor780-anti-hCD8 (eBio sciences, San Diego, CA) and washed. Stained PBMC were treated for $20 \mathrm{~min}$ at $4^{\circ} \mathrm{C}$ with $1 \mathrm{mM}$ suberic acid bis (3sulfo-N-hydroxysuccinimide ester) sodium salt crosslinker. Samples were then quenched for $15 \mathrm{~min}$ at $4^{\circ} \mathrm{C}$ with PBS containing $50 \mathrm{mM}$ Tris-HCl. Samples were fixed and permeabilized in a lithium phosphate-buffered, lithium chloride solution containing $0.1 \%$ bovine serum albumin (BSA), $4 \%$ formaldehyde, and $0.05 \%$ saponin (all from Sigma, St Louis, MO) for $25 \mathrm{~min}$ at $4^{\circ} \mathrm{C}$, and then washed once in cold lithium-based buffer plus $0.05 \%$ saponin. Samples were washed in lithium-based nuclease buffer and resuspended in lithium-based RNase buffer plus $0.05 \%$ saponin and 20 units $/ \mathrm{mL}$ RNase One (Promega) for two hours at $37^{\circ} \mathrm{C}$. Samples were then aliquoted to separate hybridization tubes and washed with the lithium-based wash buffer. Hybridization buffer $(300 \mu \mathrm{L})$ consisted of $70 \%$ formamide, $150 \mathrm{mM}$ lithium chloride, $10 \mathrm{mM}$ Tris- $\mathrm{HCl}$ and $1 \%$ BSA. Probe $(+)$ tubes received hybridization buffer plus Cy5-OO-(CCCTAA) $)_{3}$-EE PNA probe (Panagene, South Korea) at a concentration of $0.5 \mu \mathrm{g} / \mathrm{mL}$. Probe(-) tubes received hybridization buffer only. Samples were hybridized in an $82^{\circ} \mathrm{C}$ water bath for $12 \mathrm{~min}$. After overnight cooling in the dark, samples were washed twice with $1 \mathrm{~mL}$ of $70 \%$ formamide, $0.1 \%$ BSA, $150 \mathrm{mM}$ sodium chloride wash buffer, then once with $1 \mathrm{~mL}$ permeabilization wash buffer (Perm/Wash, BD Biosciences). Samples were stained with PE-Cy7-anti-hCD45RA and PE-anti-BrdU (BD Biosciences) for $1 \mathrm{~h}$ at room temperature in perm-wash buffer. Samples were washed twice and resuspended in PBS-BSA containing $0.1 \mu \mathrm{g} / \mathrm{mL}$ of 4',6-diamidino-2-phenylindole (DAPI) for flowFISH analysis.

\section{Flow cytometry}

All samples were analyzed on a FACS-Aria flow cytometer. DNA content (using the DAPI signal) and telomere probe signals were collected with linear amplification. A minimum of 30,000 lymphocyte-gated events per tube were collected. Linear calibration beads (RLP-30-5, Spherotech) were run at the end of all experiments for conversion of experimental mean fluorescence intensities (MFIs) to molecules of equivalent soluble fluorescence (MESF).

\section{Data analysis}

Flow cytometry data was analyzed using Flowjo v7.2.5 software (Treestar, Ashland, OR). Cells were sequentially gated to select for singlets, lymphocytes, 2 n DNA content $\left(G_{0} G_{1}\right.$ cells) and then $\mathrm{CD}^{+}$and $\mathrm{CD}^{+}$cell populations. Virusspecific cells were defined by BrdU staining. For TL measurement, the mean fluorescence intensity (MFI) of the probe(-) tube for each sample was subtracted from the MFI of the matching probe $(+)$ tube to obtain a specific MFI. Specific MFI values were converted to MESF using the linear bead-derived best-fit equation; linear performance in the Cy5 (telomere probe) channel was verified $\left(r^{2}>0.99\right)$ in all runs.

\section{Statistical analysis}

Statistical tests (Wilcoxon signed rank test, unpaired $t$ test, linear regression testing) were performed using Prism v5.0 (GraphPad Software). All statistical tests were two-tailed. $P$ values for linear regression tests use Pearson correlation analysis. Linear regression equation slope and intercept were computed by linear trend line fitting in MS Excel (Microsoft).

\section{Additional file}

\footnotetext{
Additional file 1: Figure S1. A component of the flowFISH telomere probe signal is sensitive to RNA nuclease treatment. Telomere lengths in $\mathrm{CD}_{5}$ RA ${ }^{+} \mathrm{T}$ cells were measured by flowFISH. Specific MFI is the difference between the average signal in triplicate Cy5-labeled probe (+) tubes and the background fluorescence in the probe (-) tube. p values were determined by Student's $t$-test on triplicate hybridizations. Limit of detection for mean fluorescence intensity (MFI) was 0.4 arbitrary units (AU). Figure S2. Comparison of CD4 and CD8 staining with and without in situ hybridization procedure. Top panels show CD4 x CD8 gating without fluorescent in situ hybridization and the subsequent $\mathrm{CD}^{+} \mathrm{BrdU}+$ population. The bottom panels show the same culture sample, but with
} 
in situ hybridization for telomere length measurement in the proliferated BrdU+ cells. The CD4 and CD8 signals are reduced by in situ hybridization, but still sufficient to allow discrimination of the BrdU+ population of proliferated T cells. Figure S3. $\mathrm{CD}^{+} \mathrm{T}$ cells in PBMC samples obtained prior to vaccination do not proliferate in vitro in response to VACV stimulation. PBMC were obtained from 5 VACV-naiive donors prior to vaccination with VACV. Frequency shown is the percent $\mathrm{BrdU}+\mathrm{CD}^{+} \mathrm{T}$ cells following stimulation with IAV, media-only, and VACV. Figure S4. Reproducibility of TL measurements by flowFISH. (A) Comparison of TL measured ex vivo by flowFISH versus in BrdU ${ }^{\text {neg }} \mathrm{T}$ cells at day 7 of culture in three different subjects. (B) FlowFISH TL measurements in virus-specific CD4+ T cells from the same subject in two different experiments. (C) Intra-assay variability in TL measurement with replicate IAV-stimulated cell cultures tested in the same experiment (dotted and solid lines). Inset panel is the mean telomere probe fluorescence and $\mathrm{BrdU}+$ cell frequencies. Histograms represent distribution of telomere length from diploid-gated $\mathrm{BrdU}+\mathrm{CD}^{+} \mathrm{T}$ cells. $\mathrm{AU}=$ arbitrary units of fluorescence.

\section{Abbreviations}

BrdU: Bromodeoxyuridine; flowFISH: Flow cytometry fluorescent in situ hybridization; CMV: Cytomegalovirus; CV: Coefficient of variation; IAV: Influenza a virus; MESF: Molecules of equivalent soluble fluorescence; MFI: Mean fluorescence intensity; PBMC: Peripheral blood mononuclear cell; TL: Telomere length; TRF: Telomere restriction fragment; VACV: Vaccinia virus; VZV: Varicella zoster virus.

\section{Competing interests}

The authors declare that they have no competing interests.

\section{Authors' contributions}

$A M, J O, A R$ defined, refined, and developed the relevant experimental approaches. AM, JO, AR and MC designed the detailed in vitro experimental work flow and determined the availability and screening of healthy blood donors. $\mathrm{JO}$ and $\mathrm{MW}$ performed the experiments. JO and $\mathrm{AM}$ analyzed the data results and created the data figures. JO, AM, and AR organized, wrote, and edited the resulting manuscript. All authors read and approved the final manuscript.

\section{Acknowledgements}

We thank John Cruz for propagating vaccinia virus stocks. We thank Karen Longtine, Jaclyn Longtine and Melissa O'Neill for their help in obtaining these PBMC samples. This work was funded by NIH grants P01 Al049320, U19 Al057319 and T32 Al007349.

\section{Author details}

'Division of Infectious Diseases and Immunology, University of Massachusetts, Medical School, Worcester MA, USA. ${ }^{2}$ Institute for Immunology and Informatics, University of Rhode Island, Providence, RI, USA.

Received: 30 January 2013 Accepted: 21 August 2013

Published: 26 August 2013

\section{References}

1. Asanuma H, Sharp M, Maecker HT, Maino VC, Arvin AM: Frequencies of memory T cells specific for varicella-zoster virus, herpes simplex virus, and cytomegalovirus by intracellular detection of cytokine expression. $J$ Infect Dis 2000, 181:859-866.

2. Hammarlund E, Lewis MW, Hansen SG, Strelow LI, Nelson JA, Sexton GJ, Hanifin JM, Slifka MK: Duration of antiviral immunity after smallpox vaccination. Nat Med 2003, 9:1131-1137.

3. Crotty S, Felgner P, Davies H, Glidewell J, Villarreal L, Ahmed R: Cutting edge: long-term $B$ cell memory in humans after smallpox vaccination. $\mathrm{J}$ Immunol 2003, 171:4969-4973.

4. Zhou J, Shen X, Huang J, Hodes RJ, Rosenberg SA, Robbins PF: Telomere length of transferred lymphocytes correlates with in vivo persistence and tumor regression in melanoma patients receiving cell transfer therapy. J Immunol 2005, 175:7046-7052.

5. Tran KQ, Zhou J, Durflinger KH, Langhan MM, Shelton TE, Wunderlich JR, Robbins PF, Rosenberg SA, Dudley ME: Minimally cultured tumor- infiltrating lymphocytes display optimal characteristics for adoptive cell therapy. J Immunother 2008, 31:742-751.

6. Fletcher JM, Vukmanovic-Stejic M, Dunne PJ, Birch KE, Cook JE, Jackson SE, Salmon M, Rustin MH, Akbar AN: Cytomegalovirus-specific CD4+ T cells in healthy carriers are continuously driven to replicative exhaustion. J Immunol 2005, 175:8218-8225.

7. Dunne PJ, Faint JM, Gudgeon NH, Fletcher JM, Plunkett FJ, Soares MV, Hislop AD, Annels NE, Rickinson AB, Salmon M, Akbar AN: Epstein-Barr virusspecific CD8(+) T cells that re-express CD45RA are apoptosis-resistant memory cells that retain replicative potential. Blood 2002, 100:933-940.

8. Reed JR, Vukmanovic-Stejic M, Fletcher JM, Soares MV, Cook JE, Orteu CH, Jackson SE, Birch KE, Foster GR, Salmon M, et al: Telomere erosion in memory T cells induced by telomerase inhibition at the site of antigenic challenge in vivo. J Exp Med 2004, 199:1433-1443.

9. van Baarle D, Nanlohy NM, Otto S, Plunkett FJ, Fletcher JM, Akbar AN: Progressive telomere shortening of Epstein-Barr virus-specific memory $T$ cells during HIV infection: contributor to exhaustion? I Infect Dis 2008, 198:1353-1357.

10. Combadiere B, Boissonnas A, Carcelain G, Lefranc E, Samri A, Bricaire F, Debre $P$, Autran B: Distinct time effects of vaccination on long-term proliferative and IFN-gamma-producing T cell memory to smallpox in humans. J Exp Med 2004, 199:1585-1593.

11. Hammarlund E, Lewis MW, Hanifin JM, Mori M, Koudelka CW, Slifka MK: Antiviral immunity following smallpox virus infection: a case-control study. J Virol 2010, 84:12754-12760.

12. Amara RR, Nigam P, Sharma S, Liu J, Bostik V: Long-lived poxvirus immunity, robust CD4 help, and better persistence of CD4 than CD8 T cells. J Virol 2004, 78:3811-3816.

13. Son NH, Murray S, Yanovski J, Hodes RJ, Weng N: Lineage-specific telomere shortening and unaltered capacity for telomerase expression in human T and B lymphocytes with age. J Immunol 2000, 165:1191-1196.

14. Macallan DC, Asquith B, Irvine AJ, Wallace DL, Worth A, Ghattas H, Zhang Y, Griffin GE, Tough DF, Beverley PC: Measurement and modeling of human T cell kinetics. Eur J Immunol 2003, 33:2316-2326.

15. Vrisekoop N, den Braber I, de Boer AB, Ruiter AF, Ackermans MT, van der Crabben SN, Schrijver EH, Spierenburg G, Sauerwein HP, Hazenberg MD, et al: Sparse production but preferential incorporation of recently produced naive T cells in the human peripheral pool. Proc Natl Acad Sci U S A 2008, 105:6115-6120.

16. Wallace DL, Zhang $Y$, Ghattas $H$, Worth $A$, Irvine A, Bennett AR, Griffin GE, Beverley PC, Tough DF, Macallan DC: Direct measurement of T cell subset kinetics in vivo in elderly men and women. J Immunol 2004, 173:1787-1794.

17. Weng NP, Levine BL, June $\mathrm{CH}$, Hodes RJ: Regulated expression of telomerase activity in human T lymphocyte development and activation. J Exp Med 1996, 183:2471-2479.

18. Valenzuela HF, Effros RB: Divergent telomerase and CD28 expression patterns in human CD4 and CD8 T cells following repeated encounters with the same antigenic stimulus. Clin Immunol 2002, 105:117-125.

19. Akbar AN, Vukmanovic-Stejic M: Telomerase in T lymphocytes: use it and lose it? J Immunol 2007, 178:6689-6694.

20. Hathcock KS, Chiang JY, Hodes RJ: In vivo regulation of telomerase activity and telomere length. Immunol Rev 2005, 205:104-113.

21. Gattinoni L, Lugli E, Ji Y, Pos Z, Paulos CM, Quigley MF, Almeida JR, Gostick E, Yu Z, Carpenito C, et al: A human memory T cell subset with stem cell-like properties. Nat Med 2011, 17:1290-1297.

22. Lugli E, Dominguez MH, Gattinoni L, Chattopadhyay PK, Bolton DL, Song K, Klatt NR, Brenchley JM, Vaccari M, Gostick E, et al: Superior T memory stem cell persistence supports long-lived T cell memory. J Clin Invest 2013. [Epub ahead of print]:doi:10.1172/JCl66327.

23. Sinclair J: Human cytomegalovirus: Latency and reactivation in the myeloid lineage. J Clin Virol 2008, 41:180-185.

24. Kennedy PG, Cohrs RJ: Varicella-zoster virus human ganglionic latency: a current summary. J Neurovirol 2010, 16:411-418.

25. Nikolich-Zugich J: Ageing and life-long maintenance of T-cell subsets in the face of latent persistent infections. Nat Rev Immunol 2008, 8:512-522.

26. Gershon AA, Gershon MD, Breuer J, Levin MJ, Oaklander AL, Griffiths PD: Advances in the understanding of the pathogenesis and epidemiology of herpes zoster. J Clin Virol 2010, 48(Suppl 1):S2-7.

27. Baerlocher GM, Lansdorp PM: Telomere length measurements in leukocyte subsets by automated multicolor flow-FISH. Cytometry A 2003, 55:1-6. 
28. Baerlocher GM, Vulto I, de Jong G, Lansdorp PM: Flow cytometry and FISH to measure the average length of telomeres (flow FISH). Nat Protoc 2006, 1:2365-2376.

29. O'Bryan JM, Potts JA, Bonkovsky HL, Mathew A, Rothman AL: Extended Interferon-Alpha Therapy Accelerates Telomere Length Loss in Human Peripheral Blood T Lymphocytes. PLoS One 2011, 6:e20922.

30. Azzalin CM, Reichenbach P, Khoriauli L, Giulotto E, Lingner J: Telomeric repeat containing RNA and RNA surveillance factors at mammalian chromosome ends. Science 2007, 318:798-801.

31. Schoeftner S, Blasco MA: Developmentally regulated transcription of mammalian telomeres by DNA-dependent RNA polymerase II. Nat Cell Biol 2008, 10:228-236.

32. Wassarman DA, Steitz JA: Structural analyses of the 7SK ribonucleoprotein (RNP), the most abundant human small RNP of unknown function. Mol Cell Biol 1991, 11:3432-3445.

33. Kapoor V, Hakim FT, Rehman N, Gress RE, Telford WG: Quantum dots thermal stability improves simultaneous phenotype-specific telomere length measurement by FISH-flow cytometry. I Immunol Methods 2009, 344:6-14.

34. Schmid I, Dagarag MD, Hausner MA, Matud JL, Just T, Effros RB, Jamieson BD: Simultaneous flow cytometric analysis of two cell surface markers, telomere length, and DNA content. Cytometry 2002, 49:96-105.

35. Larsson S, Soderberg-Naucler C, Wang FZ, Moller E: Cytomegalovirus DNA can be detected in peripheral blood mononuclear cells from all seropositive and most seronegative healthy blood donors over time. Transfusion 1998, 38:271-278.

36. Su LF, Kidd BA, Han A, Kotzin JJ, Davis MM: Virus-specific CD4(+) memoryphenotype T cells are abundant in unexposed adults. Immunity 2013, 38:373-383.

37. Miller JD, van der Most RG, Akondy RS, Glidewell JT, Albott S, Masopust D, Murali-Krishna K, Mahar PL, Edupuganti S, Lalor S, et al: Human effector and memory CD8+ T cell responses to smallpox and yellow fever vaccines. Immunity 2008, 28:710-722.

38. Hamelin C, Dion M: Modification of specific regions of the human cytomegalovirus genome during in vitro passage. Can J Infect Dis 1990, 1:48-50.

39. Weng NP, Levine BL, June $C H$, Hodes RJ: Human naive and memory $T$ lymphocytes differ in telomeric length and replicative potential. Proc Natl Acad Sci U S A 1995, 92:11091-11094.

40. Koch S, Larbi A, Ozcelik D, Solana R, Gouttefangeas C, Attig S, Wikby A, Strindhall J, Franceschi C, Pawelec G: Cytomegalovirus infection: a driving force in human T cell immunosenescence. Ann N Y Acad Sci 2007, 1114:23-35.

41. Aubert G: Hills M. Lansdorp PM: Telomere length measurement-Caveats and a critical assessment of the available technologies and tools. Mutat Res; 2011.

42. Gattinoni L, Lugli E, Ji Y, Pos Z, Paulos CM, Quigley MF, Almeida JR, Gostick E, Yu Z, Carpenito C, et al: A human memory T cell subset with stem celllike properties. Nat Med 2011. Advance Online Publication, available online Sep 18, 2011.

43. Ahlers JD, Belyakov IM: Memories that last forever: strategies for optimizing vaccine T-cell memory. Blood 2010, 115:1678-1689.

44. Yehezkel S, Segev Y, Viegas-Pequignot E, Skorecki K, Selig S: Hypomethylation of subtelomeric regions in ICF syndrome is associated with abnormally short telomeres and enhanced transcription from telomeric regions. Hum Mol Genet 2008, 17:2776-2789.

doi:10.1186/1742-4933-10-37

Cite this article as: O'Bryan et al.: Telomere length dynamics in human memory $T$ cells specific for viruses causing acute or latent infections. Immunity \& Ageing 2013 10:37.

\section{Submit your next manuscript to BioMed Central and take full advantage of:}

- Convenient online submission

- Thorough peer review

- No space constraints or color figure charges

- Immediate publication on acceptance

- Inclusion in PubMed, CAS, Scopus and Google Scholar

- Research which is freely available for redistribution

Submit your manuscript at www.biomedcentral.com/submit
Ciomed Central 